\title{
SIKAP GURU DAN TINGKAT PENGGUNAAN TEKNOLOGI INFORMASI DAN KOMUNIKASI DI KELAS SEBAGAI MEDIA PEMBELAJARAN BAHASA INGGRIS DI SMA 3 DAN SMK 1 MUHAMMADIYAH KOTA BATU
}

\author{
SUDIRAN \\ FKIP Universitas Muhammadiyah Malang \\ Email: sudiran@umm.ac.id
}

\begin{abstract}
Abstrak
Penelitian ini bertujuan untuk: (1) mengungkap sikap guru terhadap pemaanfaatan teknologi informasi internet sebagai media pembelajaran bahasa Inggris di SMA. (2) Menjelaskan tingkat kemampuan guru dalam penerapan teknologi informasi komunikasi dalam proses belajar mengajar di sekolah. (3) Menguraikan hubungan sikap guru terhadap internet dan tingkat kemampuannya menggunakan internet sebagai media pembelajaran di sekolah, dan (4) mendeskripsikan tingkat frekuensi guru dalam mengakses internet sebagai media pembelajaran di sekolah.

Penelitian menggunakan desain metode kuantitatif dan kualitatif (mixing), yang terdiri dari dua prosedur: (1) rancangan kuesioner, dan (2) penggunaan interview. Penelitian ini dilakukan di SMA 3 Muhammadiyah dan SMK 1 Muhammadiyah di kota Batu.

Hasil penelitian menunjukkan bahwa guru memiliki sikap positif terhadap pentingnya penggunaan teknologi informasi komunikasi internet sebagai media pembelajaran bahasa Inggris, guru memiliki tingkat kemampuan yang Baik ketika menggunakan teknologi informasi komunikasi dalam proses belajar mengajar di sekolah, terdapat hubungan signifikan antara sikap guru terhadap TIK dan tingkat penguasaanya sebagai media pembelajaran, dan kesulitan yang dihadapi guru dalam memanfaatkan internet sebagai media pendidikan di sekolah ada dua yaitu (1) tantangan atau kesulitan teknis dan (2) kesulitan non teknis.
\end{abstract}

Kata Kunci: teknologi informasi, media pembelajaran

\begin{abstract}
The research is purposed as follow: (1) to reveal the teachers' attitude on the use of information technology on the internet as an English learning media in senior high school (SMA). (2) to explain the level of teachers' proficiency on the application of communication information technology in the of teaching learning process at school. (3) to define the relationship between the teachers' attitude to the internet and the level of internet-using proficiency as learning media at school, and (4)to describe the level of frequency of the teacher in accessing the internet as a learning media at school.

The research used quantitative and qualitative method design (mixed), in two procedures as follow: (1) questionnaire design, and (2) use of interview. The research is conducted in SMA 3 Muhammadiyah and SMK 1 Muhammadiyah in Batu city.

The findings showed that the teachers have positive attitude towards the importance of the use of communication information technology on the internet as English learning media. The teachers have good level of proficiency in using the communication information technology in the teaching-learning process at school. There is a significant relationship between the teachers' attitude towards the communication information technology and the level of internet-using proficiency as learning media at school. There are two problems faced
\end{abstract}


by the teachers in using the internet as education media at school as follow: (1) technical challenges and difficulties, and (2) non-technical difficulties.

Key word: information communication technology,teaching media

\section{PENDAHULUAN}

Bahasa Inggris merupakan media pengembangan ilmu yang penting dalam dunia pendidikan. Termasuk di dalam dunia pendidikan Indonesia bahasa Inggris adalah bahasa asing yang pertama yang diajarkan di sekolah mulai dari sekolah dasar sampai perguruan tinggi. Oleh karena itu, pembelajaran bahasa Inggris harus senantiasa ditingkatkan kualitasnya dengan menggunakan media pembelajaran yang dapat memudahkan guru menyampaikan materi pelajaran seperti pemanfaatan teknologi informasi dan komunikasi (TIK). Pemanfaatan Teknologi informasi oleh guru di dalam kelas juga dapat membantu siswa dalam memahami materi pelajaran dengan mudah sehingga mereka mampu meningkatkan hasil belajarnya (James, 2014). Pemanfaatan teknologi informasi dan komunikasi (TIK) merupakan suatu keniscayaan dalam proses belajar mengajar di sekolah, sehingga guru dituntut agar mampu memanfaatkan TIK sebagai media pembelajaran bahasa Inggris di sekolah. Hal ini pernah diungkapkan oleh Dogan (2013 bahwa seiring dengan pesatnya peningkatan informasi dan keterampilan yang harus dipelajari siswa sebagai dampak penyebaran informasi yang tidak mungkin diajarkan oleh sekolah. Oleh karenaya, penting untuk mengajarkan seseorang tentang keterampilan bagaimana dan di mana memperoleh sumber informasi sebagai bagian dari proses pendidikan. Dengan demikian, penggunaan TIK dan internet dalam mengakses sumber informasi menjadi penting di dalam proses belajar mengajar.

Dalam dunia pendidikan, keterampilan berbahasa asing seperti, bahasa Inggris merupakan salah satu keterampilan yang penting dan mendasar yang memungkinkan seorang dapat meningkatkan prestasinya (Rimando, 2010). Penggunaan bahasa Inggris oleh guru dapat memperoleh pengalaman baru yang menjadi dasar pemerolehan ilmu pengetahuan. Seorang guru dapat mengapresiasi pengalaman siswanya melalui buku-buku atau sumbersumber tercetak lainnya. Hal ini dikarenakan semua ilmuan dan jurnalis menuliskan apa yang mereka temukan di lapangan ke dalam hasil laporan yang dipublikasikan seperti buku, majalah, atau jurnal ilmiah. Mereka umumnya mendiseminasikan konsep-konsep atau ideidenya ke dalam media massa seperti media cetak (buku, majalah, jurnal) atau media elektronik (internet). Oleh karena itu, keterampilan menggunakan bahasa Inggris merupakan keterampilan yang mendasar bagi semua orang yang ingin meningkatkan wawasan dan ilmu pengetahuan. Bahasa Ingggris merupakan keterampilan yang menuntun semua orang meraih tujuan hidupnya.

Ketika seseorang sedang mengakses informasi melalui internet, pada saat itulah keterampilan membaca dibutuhkan, terutama kemampuan membaca teks berbahasa Inggris. Oleh karena itu, kemampuan menggunakan media internet dan keterampilan membaca memiliki korelasi yang sangat kuat. Internet juga dapat digunakan untuk meningkatkan kompetensi siswa. Alasan ini merupakan fakta yang membangkitkan rasa ingin tahu peneliti untuk mengamati lebih dalam tentang sikap guru terhadap penggunaan internet sebagai media pendidikan dalam pembelajaran bahasa Inggris dikaitkan 
dengan tingkat penguasaan mereka terhadap internet.

Penelitian ini dikembangkan berdasarkan empat permasalahan utama antara lain:

1) Bagaimana sikap guru terhadap pentingnya teknologi informasi dan komunikasi (TIK) atau internet dalam pembelajaran bahasa Inggris?

2) Bagaimana tingkat penerapan TIK oleh guru sebagai media pembelajaran di kelas?

3) Bagaimana hubungan sikap guru terhadap TIK dan tingkat penguasaanya sebagai media pembelajaran di kelas?

4) Tantangan apa saja yang dihadapi guru dalam memanfaatkan TIK (internet) di sekolah?

Berdasarkan deskripsi di atas, penelitian ini bertujuan untuk:

1) Mengungkap sikap guru terhadap pemaanfaatan teknologi informasi internet sebagai media pembelajaran bahasa Inggris di SMA.

2) Menjelaskan tingkat kemampuan guru dalam penerapan teknologi informasi komunikasi dalam proses belajar mengajar di sekolah.

3) Menguraikan hubungan sikap guru terhadap TIK dan tingkat kemampuannya menggunakan internet sebagai media pembelajaran di sekolah.

4) Mendeskripsikan berbagai tantangan yang dihadapi guru dalam memanfaatkan TIK (internet) di sekolah.

Sementara itu, manfaat yang dapat disumbangkan dari penelitan ini adalah informasi tentang sikap dan tingkat penggunaan teknologi informasi dan komunikasi oleh guru dalam memanfaatkan internet sebagai media pembelajaran bahasa Inggris di sekolah. Informasi tersebut dapat memberikan pemahaman komprehensip tentang sikap guru dalam penerapan pembelajaran berbasis teknologi informasi. Selain informasi tentang sikap guru terhadap penerapan TIK, penelitian ini juga dapat memberikan sumbangan kepada para peminat pendidikan bahasa Inggris tentang tingkat penggunaan atau penguasaan guru terhadap internet sebagai media pembelajaran.

Penelitian tentang sikap guru dan tingkat kemampuan menggunakan teknologi informasi dan komunikasi (TIK) ini penting dilaksanakan karena memiliki relevansi dengan tema pada payung PPM FKIP-Universitas Muhammadiyah Malang yaitu "Pendidik Profesional yang Islami dan Berdaya Saing Unggul,” dan memiliki relevansi dengan mata kuliah yang diampu oleh peneliti yaitu language skills terutama reading comprehension.

Kemudian penelitian ini dapat memberikan sumbangan bermanfaat pada bidang ilmu pendidikan bahasa Inggris, terutama language skills (listening, speaking, reading dan writing). Penelitian ini juga dapat memberikan kontribusi pada pengembangan teori konstruktivisme, serta memberikan sumbangan kepada guru dalam meningkatkan prestasi siswa melalui penerapan internet sehingga siswa dapat menguasai pelajaran bahasa Inggris dengan mudah dan menyenangkan yang pada gilirannya dapat meningkatkan hasil belajar mereka.

Penelitian ini menganalisis sikap guru terhadap pentingnya teknologi informasi komunikasi internet dan penerapannya sebagai media pembelajaran bahasa Inggris di SMA. Dengan demikian penelitian yang akan dilakukan ini memiliki perbedaan yang signifikan dari penelitian-penelitian sebelumnya. Tinjauan pustaka ini membahas beberapa aspek sebagai kerangka teori dalam menganalisis permasalahan penelitian yaitu: sikap guru terhadap internet, penerapan internet, dan internet sebagai media pembelajaran. 
Sikap Guru Terhadap Teknologi Informasi dan Komunikasi

Penelitian yang telah dipublikasikan dalam jurnal The Turkish Online Journal of Educational Technology oleh Erguvan (2014) menunjukkan bahwa keberhasilan penerapan teknologi informasi seperti internet ke dalam pendidikan sangat bergantung kepada sikap guru yang pada akhirnya menentukan bagaimana mereka menggunakan teknologi tersebut di dalam kelas. Kemudian dalam Interdisciplinary Journal of Contemporary Research in Business, Harb et al. (2013) menyatakan bahwa subjek penelitian memiliki persepsi yang positif terhadap penerapan teknologi dalam proses belajar mengajar pada mata kuliah keterampilan listening dan speaking di perguruan tinggi. Dengan demikian, kalau Erguvan dan Harb et al meneliti tentang persepsi guru, dosen dan mahasiswa terhadap penerapan teknologi informasi dalam pembelajaran mata kuliah listening dan speaking, maka penelitian ini mengamati persepsi guru terhadap pentingnya teknologi internet sebagai media pendidikan dalam pembelajaran bahasa Inggris di SMA.

\section{Penerapan Teknologi Informasi dan Komunikasi}

Menurut Tearle (dalam Marwan, 2009), keberhasilan penerapan teknologi informasi melibatkan sebuah proses yang kompleks yang terdiri dari beberapa faktor seperti terlihat dalam bagan 1

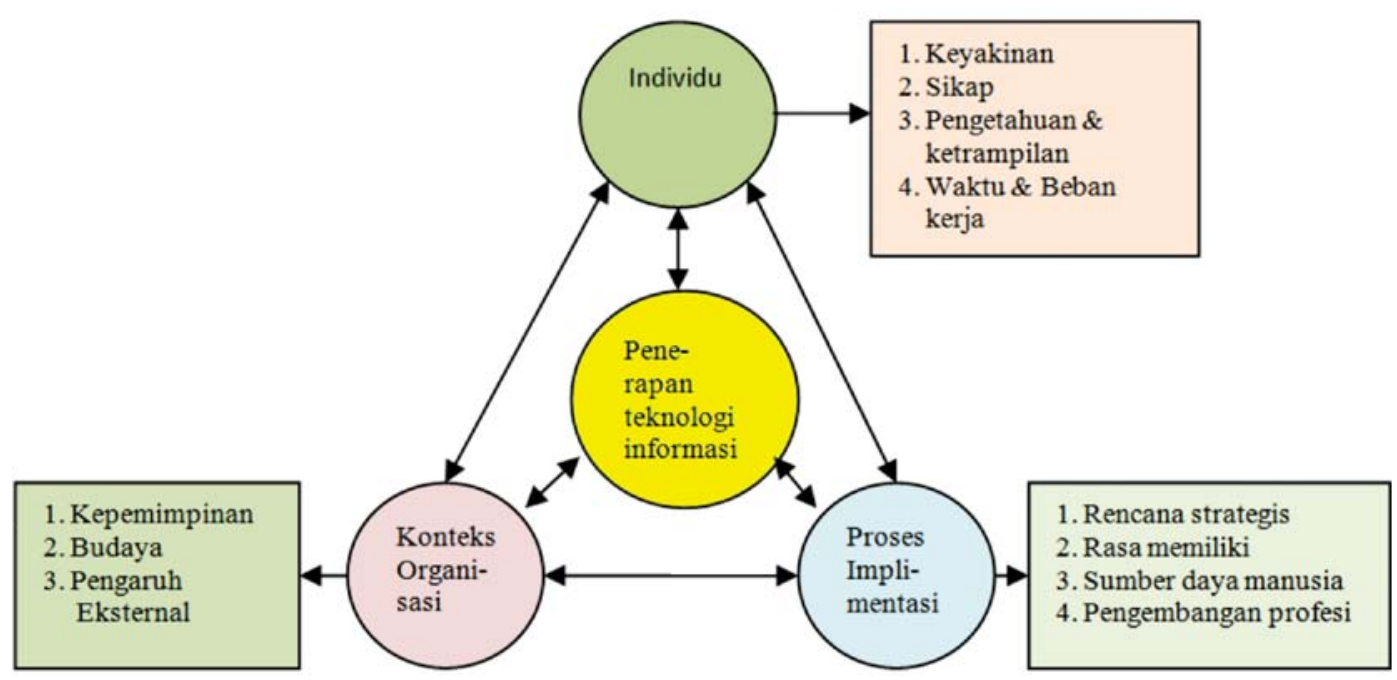

Sumber: Tearle P. (2004). "A theoretical and instrumental framework for implementing change in ICT in education." Cambridge Journal of Education, 34(3), 331-351, dalam Marwan (2009).

Ada tiga kategori penting yang mempengaruhi keberhasilan penerapan teknologi informasi. Ketiga kategori tersebut adalah Individu, Implementasi proses dan konteks organisasi. Dalam penelitian ini, peneliti menggunakan ketiga kategori tersebut karena ketiganya dapat membantu peneliti mengidentifikasi faktor-faktor utama yang mempengaruhi keberhasilan penerapan teknologi di sekolah.

\section{Teknologi Internet Sebagai Media Pembelajaran Bahasa Inggris}

Menurut Grey (1999), paling sedikit ada empat fungsi internet sebagai media pendidikan di sekolah, yaitu: (1) menelusuri 
dan Menemukan Informasi, (2) Mempublikasikan dan Menyediakan Informasi, (3) Sarana Berdialog, dan (4) Sarana Kolaborasi dan Belajar. Empat fungsi tersebut merupakan cara penerapan internet dalam pembelajaran bahasa Inggris.

Sementara itu, menurut Lee (2000), ada beberapa langkah dalam pemanfaatan internet yang perlu diperhatikan guru antara lain:

a) Siswa telah memahami konsep-konsep dasar dan penerapannya untuk melakukan aktivitas berbasis internet.

b) Pemberian tugas seperti, menggunakan email tidak terlalu mengutamakan linguistik.

c) Guru perlu membimbing siswa untuk memanfaatkan email sehingga bisa berkomunikasi secara langsung.

d) Guru perlu memberi siswa kesempatan untuk melakukan koreksi dan pengecekan email atau halaman jejaringnya (web page) sebelum pesan mereka dikirim atau dipublikasikan.

e) Jika kegiatan pembelajaran bertujuan untuk menghasilkan dan mempublikasikan jejaring, guru harus memastikan bahwa fokus utama adalah tugas bahasa, bukan desain jejaringnya.

Hal ini menunjukkan bahwa manfaat internet sebagai sarana berkomunikasi tidak dapat disangkal lagi, internet dapat digunakan sebagai sarana menerima dan mengakses informasi. Ia dapat menyediakan informasi dunia bagi pembelajar bahasa asing yang bisa diakses kapan saja.

\section{METODE}

Penelitian ini menggunakan desain metode kuantitatif dan kualitatif (mixing), yang terdiri dari dua prosedur: (1) rancangan kuesioner, dan (2) penggunaan interview. Penggunaan kedua prosedur tersebut dimaksudkan untuk memperoleh informasi tentang sikap guru terhadap teknologi informasi internet sebagai media pembelajaran bahasa Inggris, penerapan teknologi internet dalam proses belajar mengajar di kelas, dan tingkat kemampuan guru menggunakan internet dalam proses belajar mengajar sebagai media pendidikan di sekolah. Penelitian ini dilakukan di SMA 3 Muhammadiyah dan SMK 1 Muhammadiyah di kota Batu.

Penelitian ini menggunakan teknik representatif sampel yang mendukung peneliti untuk mengumpulkan data yang menggambarkan karakteristik keseluruhan populasi. Sampel dari poulasi adalah tiga orang guru bahasa Inggris dan 34 orang guru yang mengajar pelajaran selain bahasa Inggris pada SMA 3 Muhammadiyah dan SMK 1 Muhammadiyah di kota Batu sehingga total sampel pada penelitian ini adalah sejumlah 37 orang guru. Mereka diminta mengisi angket tentang sikap mereka terhadap penerapan internet di sekolah. Setelah menegembalikan lembar angket, tiga orang guru bahasa Inggris diwawancarai mengenai kegiatan belajar mengajar mereka yang menggunakan intemet. Mereka juga diwawancarai tentang tingkat kemampuan mereka menggunakan internet dalam proses belajar mengajar sebagai media pembelajaran bahasa Inggris di sekolah.

Penelitian ini memiliki dua teknik pengumpulan data yaitu: (1) teknik kualitatif, yang datanya berupa hasil interview dan observasi. Interview digunakan untuk menggali lebih dalam informasi tentang penerapan taknologi internet dalam pembelajaran bahasa Inggris, dan tingkat kemampuan guru menggunakan internet dalam proses belajar mengajar sebagai media pembelajaran bahasa Inggris di sekolah. Observasi digunakan untuk mengamati secara langsung penerapan teknologi internet oleh guru di dalam kelas. (2) Teknik kuantitatif, yang datanya berupa hasil kuesioner. Kuesioner berisi seperangkat pertanyaan yang diberikan kepada para 
guru untuk mengungkap sikap mereka terhadap penerapan teknologi internet dalam pembelajaran bahasa Inggris di sekolah.

Data yang diperoleh melalui interview dianalisis dengan menggunakan teknik interpratasi dan decoding (Harb et al., 2013). Hasil observasi digunakan untuk memperkuat analisis interpretasi dan decoding. Data yang diperoleh dari kuesioner dianalisis dengan menggunakan program SPSS 20 setelah semua jawaban kuesioner dikuantitatifkan. Setiap pemyataan kuesioner diikuti oleh lima pilihan jawaban dengan rentangan dari 1 (sangat tidak setuju) sampai 5 (sangat setuju). Penghitungan data dengan program SPSS tersebut bertujuan untuk mengetahui angka persentase, mean dan standard deviasi yang digunakan untuk menginterpretasikan data dan membuat kesimpulan.

\section{HASIL DAN PEMBAHASAN}

Penelitian ini dilakukan di dua sekolah swasta yang ada di kota Batu yaitu pertama, SMA 3 Muhammadiyah dan SMK 1
Muhammadiyah kota Batu. Jumlah keseluruhan sampel adalah 37 orang guru.

Data tentang sikap guru terhadap pentingnya penggunaan teknologi informasi komunikasi (TIK) atau internet diperoleh melalui kuesioner yang didistribusikan kepada para guru sebagai respoden. Para guru yang mengajar di SMA Muhammadiyah 3 dan SMK Muhammadiyah 1 kota Batu diminta untuk mengisi kuesioner yang mengungkapkan sikap mereka terhadap pentingnya TIK atau internet sebagai media pendidikan. Data yang diperoleh dianalisis dengan menggunakan program SPSS untuk memperoleh angka Persentase, Mean dan Standard Deviasi yang semuanya menggambarkan sikap guru terhadap pentingnya intemet serta tingkat kemampuan mereka dalam menerapkan TIK. Hasil analisis data tentang sikap guru terhadap pentingnya teknologi informasi dan komunikasi (TIK) atau internet dalam pembelajaran bahasa Inggris tergambar dalam tabel 1.

Tabel 1. Mean, Std. Deviasi dan Persentase Sikap Guru

\begin{tabular}{|c|c|c|c|c|c|c|c|c|}
\hline \multirow[b]{2}{*}{ NO } & \multirow[b]{2}{*}{ ITEM } & \multicolumn{5}{|c|}{ Persen $(\%)$} & \multirow{2}{*}{$\begin{array}{l}\text { Mea } \\
\mathrm{n}\end{array}$} & \multirow[t]{2}{*}{ Std. } \\
\hline & & SS & $\mathrm{S}$ & TT & TS & $\begin{array}{l}\text { ST } \\
\text { S }\end{array}$ & & \\
\hline 1 & $\begin{array}{l}\text { Saya merasa percaya diri menggu nakan } \\
\text { internet. }\end{array}$ & $\begin{array}{l}40, \\
5\end{array}$ & $\begin{array}{l}45 \\
9\end{array}$ & $\overline{5,4}$ & 8,1 & - & 4,19 & 0,87 \\
\hline 2 & $\begin{array}{l}\text { Saya merasa percaya diri menggunakan } \\
\text { e-mail. }\end{array}$ & $\begin{array}{l}35, \\
1\end{array}$ & $\begin{array}{l}48, \\
6\end{array}$ & 8,1 & 8,1 & - & 4,11 & 0,87 \\
\hline 3 & $\begin{array}{l}\text { Saya merasa percaya diri membuka } \\
\text { laman situs internet. }\end{array}$ & $\begin{array}{l}27 \\
0\end{array}$ & $\begin{array}{l}51, \\
4\end{array}$ & $\begin{array}{l}10, \\
8\end{array}$ & $\begin{array}{l}10 \\
8\end{array}$ & - & 3,94 & 0,91 \\
\hline 4 & $\begin{array}{l}\text { Saya merasa percaya diri menggu nakan } \\
\text { penjelajah internet seperti, yahoo, } \\
\text { google, Excite dan lain-lain }\end{array}$ & $\begin{array}{l}27, \\
0\end{array}$ & $\begin{array}{l}51 \\
4\end{array}$ & $\begin{array}{l}16, \\
2\end{array}$ & 5,4 & - & 4,00 & 0,82 \\
\hline 5 & $\begin{array}{l}\text { Saya suka menggunakan e-mail untuk } \\
\text { berkomunikasi dengan orang lain. }\end{array}$ & $\begin{array}{l}21, \\
6\end{array}$ & $\begin{array}{l}48, \\
6\end{array}$ & 8,1 & $\begin{array}{l}21, \\
6\end{array}$ & - & 3,70 & 1,05 \\
\hline 6 & $\begin{array}{l}\text { Saya senang berbicara dengan orang lain } \\
\text { tentang internet. }\end{array}$ & $\begin{array}{l}13, \\
5\end{array}$ & $\begin{array}{l}51, \\
4\end{array}$ & 8,1 & $\begin{array}{l}24, \\
3\end{array}$ & $\begin{array}{l}2 \\
7\end{array}$ & 3,48 & 1,09 \\
\hline 7 & Saya suka bekerja dengan internet. & $\begin{array}{l}16, \\
2\end{array}$ & $\begin{array}{l}59, \\
5\end{array}$ & 8,1 & $\begin{array}{l}16, \\
2\end{array}$ & - & 3,75 & 0,92 \\
\hline 8 & $\begin{array}{l}\text { Saya suka menggunakan internet dari } \\
\text { rumah. }\end{array}$ & $\begin{array}{l}21 \\
6\end{array}$ & $\begin{array}{l}45 \\
9\end{array}$ & $\begin{array}{l}10, \\
8\end{array}$ & $\begin{array}{l}21 \\
6\end{array}$ & - & 3,67 & 1,05 \\
\hline 9 & $\begin{array}{l}\text { Saya percaya menggunakan internet } \\
\text { sangat bermanfaat. }\end{array}$ & $\begin{array}{l}37, \\
8\end{array}$ & $\begin{array}{l}54, \\
1\end{array}$ & 2,7 & 5,4 & - & 4,24 & 0,76 \\
\hline
\end{tabular}

Sudiran, Sikap guru dan Tingkat Penggunaan Teknologi Informasi dan Komunikasi di Kelas Sebagai Media Pembelajaran Bahasa Inggris di SMA dan SMK 1 Muhammadiyah Kota Batu 


\begin{tabular}{|c|c|c|c|c|c|c|c|c|}
\hline \multirow[b]{2}{*}{ NO } & \multirow[b]{2}{*}{ ITEM } & \multicolumn{5}{|c|}{ Persen (\%) } & \multirow{2}{*}{$\begin{array}{l}\text { Mea } \\
\mathrm{n}\end{array}$} & \multirow[t]{2}{*}{ Std. } \\
\hline & & SS & $\mathrm{S}$ & TT & TS & $\begin{array}{l}\text { ST } \\
\text { S }\end{array}$ & & \\
\hline 10 & $\begin{array}{l}\text { Internet membantu saya memperoleh } \\
\text { in fromasi. }\end{array}$ & $\begin{array}{l}45, \\
9\end{array}$ & $\begin{array}{l}54, \\
1\end{array}$ & $\overline{-}$ & $\overline{-}$ & - & 4,45 & 0,50 \\
\hline 11 & $\begin{array}{l}\text { Saya percaya internet membuat } \\
\text { komunikasi lebih mudah. }\end{array}$ & $\begin{array}{l}43, \\
2\end{array}$ & $\begin{array}{l}43, \\
2\end{array}$ & 5,4 & 8,1 & - & 4,21 & 0,88 \\
\hline 12 & $\begin{array}{l}\text { Multimedia internet seperti gambar dan } \\
\text { teks sangat membantu memahami } \\
\text { in formasi online. }\end{array}$ & $\begin{array}{l}32, \\
4\end{array}$ & $\begin{array}{l}56, \\
8\end{array}$ & 2,7 & 8,1 & - & 4,13 & 0,82 \\
\hline 13 & $\begin{array}{l}\text { Saya yakin internet memiliki potensi } \\
\text { sebagai a lat belajar. }\end{array}$ & $\begin{array}{l}43, \\
2\end{array}$ & $\begin{array}{l}51, \\
4\end{array}$ & - & 5,4 & - & 4,32 & 0,74 \\
\hline 14 & $\begin{array}{l}\text { Saya yakin internet dapat memudahkan } \\
\text { aktivitas belaiar online belaiar. }\end{array}$ & $\begin{array}{l}32 \\
4 \\
\end{array}$ & $\begin{array}{l}56, \\
8\end{array}$ & 2,7 & 8,1 & - & 4,13 & 0,82 \\
\hline 15 & $\begin{array}{l}\text { Saya yakin mempelajari intemet sangat } \\
\text { bermanfaat. }\end{array}$ & $\begin{array}{l}37, \\
8\end{array}$ & $\begin{array}{l}51, \\
4\end{array}$ & 2,7 & 8,1 & - & 4,19 & 0,84 \\
\hline 16 & $\begin{array}{l}\text { Mempelajari keterampilan internet dapat } \\
\text { meningkatkan prestasi mengaiar sava. }\end{array}$ & $\begin{array}{l}29, \\
7\end{array}$ & $\begin{array}{l}54, \\
1\end{array}$ & 8,1 & 8,1 & - & 4,05 & 0,84 \\
\hline
\end{tabular}

Seperti terlihat dalam tabel 1, guru memberikan respon terhadap 16 pernyataan yang mengungkapkan sikap mereka terhadap pentingnya penggunaan teknologi internet sebagai media pembelajaran bahasa Inggris di sekolah.

Melihat besarnya angka hasil kuesioner yaitu, $100 \%$ dari responden yang menjawab bahwa mereka setuju atau sangat setuju dengan pernyataan, "Internet membantu saya memperoleh infromasi," dengan angka mean sebesar 4,45 dan standard deviasi 0.50 , dapat dikatakan bahwa pada umumnya para guru di kedua sekolah SMA Muhammadiyah 3 dan SMK Muhammadiyah 1 Batu memiliki sikap yang positif terhadap pemanfaatan TIK atau internset sebagai media pembelajaran bahasa Inggris di dalam kelas.

Kaitan antara sikap dan tingkat atau level penerapan teknologi informasi dan komunikasi (TIK) seperti internet oleh seorang guru adalah kalau seorang guru memiliki sikap yang positif terhadap pentingnya TIK atau internet, guru tersebut akan memiliki kecenderungan untuk mampu memanfaatkan teknologi tersebut. Kemampuan untuk menggunakan atau mengoperasikan perangkat TIK merupakan bentuk respon seorang guru terhadap sikapnya yang mendukung pemanfaatan internet sebagai media pembelajaran di sekolah. Oleh karena itu, sebagai dampak dari sikap positif terhadap penerapan TIK, perlu adanya penelitian yang mengungkapkan tingkat kemampuan guru dalam menggunakan peralatan TIK. Data yang menggambarkan tingkat penerapan teknologi informasi dan komunikasi (TIK) oleh guru sebagai media pembelajaran di kelas diperoleh dengan cara menyebarkan angket kepada guru-guru yang mengajar di kedua sekolah SMA Muhammadiyah 3 dan SMK Muhammadiyah 1 kota Batu. Hasil analisis angket tentang penggunaan TIK atau internet tersebut terlihat dalam tabel 2.

Tabel 2. Mean, Std. Deviasi dan Persentase Tingkat Kemampuan TIK Guru

\begin{tabular}{|l|l|l|l|l|l|}
\hline \multirow{2}{*}{ NO } & \multirow{2}{*}{ PERNY ATAAN } & \multicolumn{2}{|c|}{ Perssen (\%) } & Mean & \multirow{2}{*}{ Std. } \\
\cline { 3 - 4 } & & Ya & Tidak & & \\
\hline $\mathbf{1}$ & Saya dapat membuka internet. & 91,9 & 8,1 & 1,92 & 0,27 \\
\hline $\mathbf{2}$ & Saya dapat membuka website atau a lamat internet. & 89,2 & 10,8 & 1,89 & 0,31 \\
\hline
\end{tabular}




\begin{tabular}{|c|c|c|c|c|c|}
\hline \multirow{2}{*}{ NO } & \multirow{2}{*}{ PERNYATAAN } & \multicolumn{2}{|c|}{ Perssen (\%) } & \multirow[t]{2}{*}{ Mean } & \multirow[t]{2}{*}{ Std. } \\
\hline & & Ya & Tidak & & \\
\hline 3 & $\begin{array}{l}\text { Saya dapat membuka laman internet untuk } \\
\text { mendapatkan banyak informasi. }\end{array}$ & 89,2 & 10,8 & 1,89 & 0,31 \\
\hline 4 & $\begin{array}{l}\text { Saya dapat membuka link untuk membuka laman } \\
\text { baru. }\end{array}$ & 78,4 & 21,6 & 1,78 & 0,41 \\
\hline 5 & Saya dapat membuka laman baru. & 83,8 & 16,2 & 1,84 & 0,37 \\
\hline 6 & $\begin{array}{l}\text { Saya dapat member ikan Bookmark atau menambah } \\
\text { halaman favorite. }\end{array}$ & 67,6 & 32,4 & 1,68 & 0,47 \\
\hline 7 & Sava dapat menvimpan gambar dari sebuah website. & 81.1 & 18.9 & 1.81 & 0.39 \\
\hline 8 & Sava dapat menvimpan teks dari website. & 81.1 & 18.9 & 1.81 & 0.39 \\
\hline 9 & Sava dapat mengetahui virus dari internet. & 54.1 & 45.9 & 1.54 & 0.50 \\
\hline 10 & Sava dapat mengecek email (surat elektronik). & 83.8 & 16.2 & 1.84 & 0.37 \\
\hline 11 & Sava dapat mengirim email. & 83.8 & 16.2 & 1.84 & 0.37 \\
\hline 12 & Sava dapat membaca email. & 83.8 & 16.2 & 1.84 & 0.37 \\
\hline 13 & $\begin{array}{l}\text { Saya dapat membuka dan membaca attachments } \\
\text { (lampiran). }\end{array}$ & 67,6 & 32,4 & 1,68 & 0,47 \\
\hline 14 & Saya dapat mengirim sebuah attachment (lampiran). & 67,6 & 32,4 & 1,68 & 0,47 \\
\hline 15 & Saya dapat menyimpan alamat email. & 78,4 & 21,6 & 1,78 & 0,41 \\
\hline 16 & Saya dapat Forward (meneruskan) pesan. & 86,5 & 13,5 & 1,86 & 0,34 \\
\hline 17 & $\begin{array}{l}\text { Saya dapat mengirimkan email kepada sekelo mpok } \\
\text { orang. }\end{array}$ & 73,0 & 27,0 & 1,75 & 0,43 \\
\hline 18 & Sava dapat Print (mencetak) email. & 78.4 & 21.6 & 1.78 & 0.41 \\
\hline 19 & Sava dapat membuat akun email. & 78.4 & 21.6 & 1.78 & 0.41 \\
\hline 20 & $\begin{array}{l}\text { Saya dapat mengelola pesan-pesan dalam folder } \\
\text { (arsip). }\end{array}$ & 78,4 & 21,6 & 1,78 & 0,41 \\
\hline
\end{tabular}

Tabel 2 menunjukkan tingkat kemampuan guru atau responden dalam menggunakan teknologi informasi dan komunikasi (TIK) sebagai media pembelajaran di sekolah.

Memperhatikan angka persentase, mean dan standard deviasi dari masing masing pernyataan dalam tabel 2 tersebut yang nilainya berada dalam rentang antara $54,1 \%$ sampai $91,9 \%$, maka dapat dikatakan bahwa pada umumnya guru SMA Muhammadiyah 3 dan SMK Muhammadiyah 1 Batu memiliki kemampuan dalam memanfaatkan teknologi informasi internet sebagai media pendidikan di sekolah. Dari hasil analisis data yang berhasil diperoleh melalui angket, dapat dikatakan bahwa guru yang menjadi responden dalam penelitian ini memiliki tingkat pemahaman dan penerapan TIK yang cukup tinggi. Hal ini berarti mereka memiliki sikap positif terhadap penerapan internet, dan hal ini ditunjukkan dengan keterampilan mereka menggunakan internet ketika mengajar di dalam kelas.

Setelah dilakukan uji validitas dan reliabilitas terhadap kedua alat ukur (angket), hasil analisis data tentang sikap guru terhadap pentingnya internet dikorelasikan dengan analisis data tentang tingkat penggunaan TIK di dalam kelas. Adapun dari uji validitas dan reliabilitas diperoleh hasil sebagai berikut:

1) Untuk angket sikap guru nilai uji validitas adalah Sig. $=0,000-0,004<$ 0,05 . Ini berarti dari ke-16 pernyataan angket, nilai signifikan berada dalam rentang antara 0,000 sampai 0,004. Sementara nilai signifikansi tabel adalah 0,05 sehingga signifikansi hitung $(0,000$ $-0,004)$ lebih kecil dari nilai tabel $(0,05)$. Oleh karena itu, ke-16 butir soal angket sebagai instrumen penelitian adalah valid. Sedangkan nilai reliabilitas ke-16 butir soal angket tentang sikap guru adalah $\mathrm{r}=0,956$. 
Menurut Sekaran (1992) dalam Priyatno (2012), nilai reliabilitas di atas 0,8 adalah baik. Dengan demikian ke-16 butir soal angket tentang sikap guru adalah reliabel.

2) Angket tingkat kemampuan guru menggunakan TIK nilai uji validitasnya adalah sig. $=0,000-0,189<0,05$. Artinya dari ke-20 butir soal angket, nilai signifikannya berada dalam rentang antara 0,000 sampai 0,189. Sedangkan nilai signifikan tabel adalah 0,05 . Dengan demikian, signifikansi hitung $(0,000-0,189)$ lebih kecil dari nilai tabel $(0,05)$. Oleh karena itu, ke20 butir soal angket tentang tingkat kemampuan guru menggunakan TIK adalah valid. Sementara itu, nilai reliabilitasnya adalah $0,971>0,8$ sehingga nilai reliabilitasnya tinggi.

Hasil korelasi antara sikap guru terhadap TIK dan tingkat penguasaanya sebagai media pembelajaran di kelas adalah $\mathrm{r}=0,786$ dengan sig. $=0,000<0,05$. Dengan demikian, dapat disimpulkan bahwa ada hubungan yang signifikan antara sikap guru terhadap TIK dan tingkat penguasaanya. Dengan kata lain, jika guruguru memiliki sikap positif terhadap pentingnya TIK, mereka cenderung berusaha meningkatkan kemampuannya menggunakan teknologi tersebut.

Berdasarkan hasil interview dengan para guru di SMA Muhammadiyah 3 dan SMK Muhammadiyah 1 kota Batu, dapat dikatakan bahwa mereka pada umumnya sudah tidak asing lagi dengan TIK atau internet sebagai media pendidikan di sekolah. Mereka menyatakan bahwa guru bahasa Inggris dalam memanfaatkan teknologi internet, telah menggunakan cara yang telah dirancang sendiri yaitu, melalui beberapa tahap mulai dari proses penentuan topik pelajaran, penyampaian materi pelajaran di kelas dan proses penilaian terhadap kemajuan siswa. Pada tahap pertama, mereka melakukan persiapan dengan menetapkan pokok bahasan dan materi yang akan disampaikan kepada siswa. Materi yang mereka gunakan merupakan hasil mengunduh (download) dari internet. Setelah mereka memperoleh materi pelajaran yang akan disampaikan, kemudian diseleksi dan disesuaikan dengan kompetensi dan tujuan pembelajaran.

Pada tahap kedua, guru melaksanakan pembelajaran di dalam kelas dengan menggunakan materi yang telah dipersiapkan dari hasil mengunduh intemet. Dalam proses pembelajaran, guru memperkenalkan kepada siswa tentang materi berbasis internet yang akan dipelajari. Dari perkenlan dengan materi pelajaran berbasis internet tersebut guru mejelaskan tentang manfaat internet dalam meningkatkan hasil belajar melalui sumber informasi yang tersedia dalam internet. Setelah selesai menyampaikan materi pelajaran berbasis internet, guru melaksanakan tahap ke tiga yaitu, penilaian. Pada tahap ini guru melakukan evaluasi tentang kelebihan dan kekurangan materi pelajaran yang telah disampaikan kepada siswa. Hasil evaluasi tersebut dijadikan bahan untuk menentukan materi palajaran selanjutnya yang sesuai dengan kemampuan siswa. Hasil evaluasi oleh guru itu juga penting untuk memilih bahan pelajaran selanjutnya dari berbagai alamat websites yang menyediakan beragam materi pelajaran yang sesuai dengan tuntutan kurikulum.

Pentahapan mengakses dan menggunakan materi pelajaran berbasis internet tersebut menuntjukkan bahwa para guru di lingkungan SMA Muhammadiyah 3 dan SMK Muhammadiyah 1 Batu pada umumnya telah berhasil memanfaatkan teknologi informasi sebagai media pembelajaran di sekolah. Ada tiga faktor penting yang mempengaruhi keberhasilan penerapan teknologi informasi. Ketiga 
faktor tersebut adalah kepribadian, proses penerapan dan Lingkungan Kerja.

\section{Faktor Kepribadian}

Sebagai pribadi pendidik, guru memiliki empat kompotensi yang harus selalu dikembangkan guna menigkatkan kualitas pembelajaran di dalam kelas yaitu: (1) kompetensi pedagogik, (2) kompetensi profesional, (3) kompetensi sosial dan (4) kompetensi kepribadian (individu). Sebagai individu guru memiliki seperangkat unsur kepribadian yang harus dibina agar menjadi individu atau pribadi yang mantap, stabil, dewasa, arif, dan berwibawa, sehingga menjadi teladan bagi peserta didik dan memiliki perilaku atau berakhlak mulia. Dalam penerapan teknologi informasi dan komunikasi, faktor individu memegang peran yang menentukan karena dalam diri setiap individu terkandung empat komponen yang mempengaruhi dirinya untuk selalu berkembang menjadi lebih trampil sebagai guru. Keempat komponen tersebut adalah: keyakinan, sikap, pengetahuan dan ketrampilan, dan waktu dan beban kerja.

\section{Kesulitan Non-Teknis}

Ada dua bentuk kesulitan non teknis yaitu, kurangnya motivasi siswa dan kurangnya pengetahuan dan keterampilan siswa.

\section{Kurangnya Motivasi Siswa}

Meskipun pembelajaran bahasa Inggris melalui internet memiliki keunggulan dibandingkan dengan yang tanpa menggunakan internet, tetapi ada beberapa siswa yang kurang termotivasi dengan pembelajaran melalui internet. Hal ini pernah diungkapkan oleh seorang guru mata pelajaran bahasa Inggris pada lokasi penelitian. Siswa yang kurang motivasi tersebut terlihat dari perilakunya ketika mengikuti pelajaran. Mereka terlihat kurang antusias bahkan terlihat merasa bosan ketika mengikuti pelajaran.

Mengatasi kendala non-teknis seperti itu, menurut guru dalam wawancara, siswa diberi pelajaran bahasa Inggris dengan menggunakan media pembelajaran seperti power point yang menarik. Guru harus menyiapkan materi pelajaran dengan perangkat media pembelajaran yang dapat membangkitkan rasa ingin tahu siswa. Dalam proses pembelajaran, siswa yang terllihat merasa bosan tersebut dilibatkan dalam diskusi atau pemecahan masalah sehingga mereka merasa menjadi bagian dari kegiatan belajar mengajar.

\section{Kurangnya Pengetahuan dan Keterampilan Siswa}

Tingkat pengetahuan dan keterampilan siswa terhadap teknologi informasi dan komunikasi (TIK) berbeda satu sama lain sehingga mereka memiliki kamampuan yang tidak sama dalam mengoperasikan komputer. Mereka yang memiliki pengetahuan TIK yang lebih baik tidak memiliki kesulitan dalam mengakses internet dan mereka dapat mengakses informasi lebih cepat dari pada mereka yang belum memiliki pengetahuan sama sekali terhadap pemanfaatan TIK. Perbedaan tingkat pengetahuan terhadap TIK di kalangan siswa membuat guru harus menyediakan waktu untuk menjelaskan cara mengakses internet bagi yang pengetahuan internetnya masih lemah. Penjelasan penggunaan TIK kepada siswa dapat mengurangi waktu jam pelajaran sehingga waktu yang tersedia untuk menyampaiakan materi pelajaran menjadi berkurang.

Menurut guru dalam interview, masalah non-teknis tersebut dapat diatasi dengan membentuk kelompok kecil yang terdiri dari tiga orang setiap kelompok. Kemudian guru mengklasifikasikan siswa sesuai tingkat 
pengetahuannya. Siswa yang memiliki pengetahuan TIK tinggi dijadikan ketua kelompok. Sedangkan siswa yang pengetahuannya tentang TIK lemah dijadikan anggota kelompok. Dengan demikian, setiap kelompok terdiri dari siswa yang memiliki tingkat pengetahuan TIK berbeda. Melalui cara ini diharapkan siswa dapat saling belajar atau saling bertukar informasi sehingga siswa yang belum mengetahui cara mengoperasikan komputer dapat belajar dengan bantuan teman sekelompok. Cara yang demikian itu ternyata memiliki manfaat ganda yaitu, pertama dapat meningkatkan pengetahuan siswa tentang TIK, dan kedua dapat membantu guru dalam menghemat waktu untuk penyampaian materi pelajaran.

Beradsarkan hasil penelitian dapat dibahas bahwa guru memiliki sikap yang positif terhadap pemanfaatan TIK atau internset sebagai media pembelajaran bahasa Inggris dan penerapannya di dalam kelas. Sikap guru yang positif tersebut memiliki kontribusi terhadap penerapan TIK di lingkungan sekolah. Mereka umumnya mampu menerapkan TIK dalam proses belajar mengajar yang memanfaatkan fasilitas internet sebagai media pembelajaran bahasa Inggris di SMA dan SMK. Kemampuan menerapkan TIK dalam pembelajaran merupakan suatu tuntutan bagi guru karena teknologi informasi dan komunikasi (TIK) telah mempengaruhi pengajaran bahasa Inggris dan pembelajaran menjadi lebih efektif dengan menggunakan TIK (Ebrahimi et al 2013).

Sikap merupakan kecenderungan seseorang untuk berperilaku sesuai dengan norma-norma sosial yang berlaku di dalam suatu masyarakat. Hal ini dikarenakan sikap adalah suatu reaksi emosi seseorang dalam merespon atau menanggapi berbagai perosalan atau opini yang tengah berkembang dalam masyarakat. Respon tersebut bisa merupakan pemberian dukungan (favorable) atau menolak (unfavorable). Seseorang yang merespon baik atau mendukung suatu opini atau gejalagejala perilaku sosial yang sedang menjadi tren berarti dia telah memiliki sikap positif terhadap opini tersebut. Sebaliknya, jika orang itu merespon kurang baik atau cenderung menolak berarti dia bersikap negatif terhadap opini atau gejala sosial yang sedang berkembang di masyarakat. Dengan demikian, sikap merupakan kecenderungan seseorang dalam berperilaku baik menerima atau menolak terhadap informasi atau persoalan yang sedang menggejala.

berdasarkan hasil analisis data terungkap bahwa responden telah menerapkan teknologi informasi dan komunikasi (TIK). Mereka sebagai guru pada umumnya telah memiliki keyakinan, sikap, pengetahuan dan ketrampilan, waktu dan beban kerja terkait dengan penerapan TIK. Dalam hal ini, sikap merupakan suatu bentuk reaksi emosi seseorang yang mendukung atau menolak terhadap objek atau kondisi soasial tertentu dalam lingkungan masyarakat. Sebagai suatu reaksi emosi atau perasaan, sikap memiliki tiga unsur yang saling berkaitan yaitu, kognitif, afektif dan konatif atau kecenderungan berperilaku. Memperhatikan unsur yang ada pada sikap, maka dapat dikatakan bahwa sikap merupakan pola perilaku seseorang untuk mendukung (positif) atau menolak (negatif) terhadap objek atau kondisi sosial yang dihadapi dalam lingkungan masyarakatnya. Sikap positif atau negatif seseorang ditentukan oleh ketiga unsur sikap: kognitif (pengetahuan dan keyakinan), afektif (emosi atau perasaan) dan konatif (kecenderungan berperilaku).

Dalam penerapan teknologi informasi seperti internet, sumber daya manusia memainkan peran yang penting. Guru 
merupakan faktor dominan dalam upaya peningkatan kualitas layanan pendidikan. Hal ini dikarenakan guru merupakan perancang sekaligus pelaksana dari perencanaan yang mereka lakukan tentang implimentasi teknologi informasi yang memudahkan mereka mengembangkan sekolah dan meningkatkan kualitas proses belajar mengajar. Guru merupakan agen pengembangan kualitas pembelajaran sehingga mereka harus dilibatkan dalam berbagai aktivitas yang bertujuan untuk meningkatkan pengetahuan dan keterampilan yang pada gilirannya meningkatkan mutu sekolah dalam membina suasana kehidupan akademis.

Meskipun responden pada umumnya telah melaksanakan pembelajaran berbasis internet, bukan berarti mereka tidak memiliki tantangan atau kesulitan dalam menerapkan teknologi informasi dan komunikasi. Hasil analisis data menunjukan mereka para guru menghadapi beberapa kesulitan dalam menerapkan TIK sebagai media pembelajaran di dalam kelas. Kesulitankesulitan tersebut dapat dikelompokkan ke dalam dua kategori yaitu: kesulitan teknis dan non teknis. Unsur yang termasuk dalam kesulitan teknis adalah, (1) terbatasnya komputer di lab bahasa, (2) terbatasnya LCD dan laptop/komputer di sekolah. (3) Terbatasnya multimedia di kelas sehingga guru memerlukan waktu ekstra untuk persiapan perangkat pembelajaran, (4) Persiapan yang digunakan untuk memasang perangkat komputer sering memakan waktu yang lama. (5) Komputer di lababoratorium bahasa kadang mengalami gangguan (error) sehingga harus dibetulkan terlebih dan pembetulan tersebut membutuhkan waktu lama. (6) Program yang digunakan guru masih sangat terbatas, sehingga tidak dapat menampilkan gambar animasi menarik dan mendukung kegiatan belajar mengajar.
Sementara itu yang tergolong kesulitan non teknis adalah: (1) Siswa merasa bosan karena terlalu sering menggunkan liquid crystal display (LCD) dan mereka tidak bisa langsung praktek sehingga tergantung kepada penjelasan guru. (2) Penggunaan internet kadang disalahgunakan oleh sebagian siswa untuk mengakses situssitus yang tidak penting dan berbahaya. (3) Pemanfaatan komputer dan internet di sekolah masih terbatas, hanya digunakan untuk mengunduh materi tambahan dan facebook. (4) Pemanfaatan komputer dan internet hanya untuk mencari bahan tugas mandiri dan kelompok bagi siswa, belum digunakan sebagai media pembelajaran secara maksimal.

\section{SIMPULAN}

Berdasarkan hasil penelitian dapat disimpulkan bahwa:

(1) Sikap guru terhadap pentingnya penggunaan teknologi informasi komunikasi internet sebagai media pembelajaran bahasa Inggris adalah positif. Hal ini didukung oleh hasil analisis data menggunakan program SPSS versi 20. Hasil penghitungan menunjukkan bahwa angka persentase tertinggi dari respon guru yang sekaligus menunjukkan sikap positif mereka adalah pada pernyataan nomor 10 yaitu, "Internet membantu saya memperoleh infromasi." (100\% dari responden menjawab bahwa mereka "setuju atau sangat setuju" dengan pernyataan tersebut), dengan angka mean $(\mathrm{M}=4,45)$ dan standard deviasi $(\mathrm{SD}=0.50)$. Angka persentase tersebut memiliki arti bahwa para guru sebagai pendidik di SMA Muhammadiyah 3 dan SMK Muhammaiyah 1 Batu memiliki sikap positif terhadap pemanfaatan teknologi informasi dan komunikasi sebagai media pembelajaran di kelas.

1) Tingkat kemampuan guru dalam penerapan teknologi informasi komunikasi 
dalam proses belajar mengajar di sekolah dapat dikategorikan baik. Hal ini terbukti dari angka persentase tertinggi terhadap respon guru yang sekaligus menunjukkan tingkat kemampuan mereka dalam menggunakan internet yang dapat dilihat pada pernyataan nomor 1 yaitu, "Saya dapat membuka internet,” (91,9\% dari responden menjawab bahwa mereka menyatakan "Ya" dengan pernyataan tersebut), dengan angka mean ( $\mathrm{M}=1,92)$ dan standard deviasi ( $\mathrm{SD}=0.27$ ). Hal ini berarti guru SMA Muhammadiyah 3 dan SMK Muhammaiyah 1 Batu telah memiliki keterampilan dalam mengoperasikan teknologi informasi dan komunikasi. Keterampilan tersebut telah diungkapkan dengan pernyataan yang menunjukan kemampuan mereka dalam membuka internet sebagai sumber informasi yang dapat dijadikan materi pelajaran bahasa Inggris.

1) Hasil korelasi antara sikap guru terhadap TIK dan tingkat penguasaanya sebagai media pembelajaran di kelas adalah $\mathrm{r}=$ 0,786 dengan sig. $=0,000<0,05$. Dengan instrumen penelitian yang telah diuji validitas dan reliabilitasnya. Oleh karena itu, dapat disimpulkan bahwa ada hubungan yang signifikan antara sikap guru terhadap TIK dan tingkat penguasaanya. Dengan kata lain, jika guru-guru memiliki sikap positif terhadap pentingnya TIK, mereka cenderung berusaha meningkatkan kemampuannya menggunakan teknologi tersebut. Kemampuan mereka dalam memanfaatkan dan mengakses internet dapat memperkaya materi pelajaran sehingga mereka mampu meningkatkan hasil belajar siswa. Pengalaman mereka dalam menggunakan internet sebagai media pembelajaran dapat meningkatkan keyakinan mereka terhadap pentingnya penguasaan TIK. Keyakinan dan pengetahuan merupakan unsur dari sikap sehingga kalau keyakinan dan pengetahuan guru terhadap pemanfaatan internet meningkat, kecenderungan mereka untuk meningkatkan pengetahuan den keterampilan tentang internet sebagai bagian dari TIK turut meningkat.

2) Tantangan atau kesulitan yang dihadapi guru dalam memanfaatkan internet sebagai media pendidikan di sekolah dapat dikategorikan ke dalam dua kelompok. pertama, tantangan atau kesulitan teknis yang meliputi, komputer yang mengalami error (kesalahan teknis), jaringan internet yang mengalami koneksi lemah pada jam-jam tertentu, dan pemadaman arus listrik yang menyebabkan semua jaringan komputer dan internet tidak berfungsi. Kedua, kesulitans non-teknis yang meliputi, kurangnya motivasi siswa, siswa sering merasa jenuh ketika belajar di dalam kelas, dan kurangnya pengetahuan dan keterampilan sebagian siswa dalam mengakses internet. Siswa yang memiliki pengetahuan terbatas dalam bidang TIK ini dapat dilihat dari cara mereka mengoperasikan komputer yang cenderung memerlukan waktu lebih lama dari pada mereka yang telah mengerti dan terbiasa dengan internet.

Berdasarkan hasil penelitian maka dapat dikemukakan saran sebagai berikut

Penelitian ini mengamati sikap guru terhadap pentingnya teknologi informasi dan komunikasi internet dan tingkat kemampuannya dalam memanfaatkan internet sebagai media pembelajaran bahasa Inggris. Dari segi kompleksitas variabel, penelitian ini perlu dikembangkan lebih lanjut agar memiliki keluasan bidang kajian. Penelitian dengan tema sikap dan 
penerapan teknologi informasi dan komunikasi sebagai media pedidikan masih perlu dikembangkan karena masih belum banyak diminati oleh para peneliti pada umumnya.

\section{DAFTAR PUSTAKA}

Arslan, Recep Sahin. 2014. "Integrating Feedback Into Prospective English Language Teachers' Writing Process Via Blogs And Portfolios." The Turkish Online Journal of Educational Technology - January 2014, volume 13 issue 1. Pp.131150

DiBlas, Nicoletta \& Paolini, Paolo. 2013. Beyond the school's boundaries: PoliCultura, a Large-scale Digital storytelling Inniciative. Educational Technology \& Society, 16 (1), 1527.

Dogan, Yadigar. 2013. "Teachers and Students' Benefiting from Computers for Instructional Purposes: Bursa Example.” Kamla-Raj Anthropologist, 16 (1-2): 133-143 (2013)

Ebrahimi, Nabi A., Zahra Eskandari, dan Ali Rahimi. 2013. Teaching English with Technology Journal. "The Effects Of Using Technology And The Internet On Some Iranian Efl Students' Perceptions Of Their Communication Classroom Environment.” Vol. 13. Issue 1, PP. 3-19, http://www.tewtjournal.org.

Erdem, Mukaddes and Kibar, Pinar Nuhoglu. 2014. “Students' Opinions On Facebook Supported Blended Learning Environment.” The Turkish Online Journal of Educational Technology - January 2014, volume 13 issue 1, Pp. 199-206

Erguvan, Deniz. 2014 'Instructors' Perceptions Towards The Use Of An Online Instructional Tool In An Academic English Setting In Kuwait.”
The Turkish Online Journal of Educational Technology - January 2014, volume 13 issue 1. Pp.115130.

Grey, D. (1999). The Internet in School. London and New York: Cassell.

Harb, Jibrel; Nadzrah Abu Bakar; Pramela Krish. 2013. “Instructors' And Students' Perceptions Towards Using Technology In Teaching And Learning Listening And Speaking At Jordanian Universities." Interdisciplinary Journal Of Contemporary Research In Business. January 2013 VOL 4, NO 9, pp. 1027-1041. ijcrb. webs. com.

Horvat, Jasna, Gregor Petri, Martina Mikrut. 2004. Measuring Computer and Web Attitudes Using Cas and Was Measurement Instruments. http:/ /bib.irb.hr/datoteka/156460. horvat petric mikru fin.pdf

Hutchison, Amy and David Reinking. 2011. “Teachers' Perceptions of Integrating Information and Communication Technologies Into Literacy Instruction: A National Survey in the United States". Academic Journal of Reading Research Quarterly. OctDec 2011, Vol. 46 Issue 4, p. 312.

Jasmadi. Panduan Praktis Menggunakan Fasilitas Internet. Yogyakarta: C.V. Andi.2004.

James, Laurie. 2014. "The Integration of A Computer-Based Early Reading Program To Increase English Language Learners' Literacy Skills.” Teaching English with Technology, 14(1), 9-22, http://www. tewtjournal. org

Lee, Kuang-wu . 2000. "Energizing the ESL/EFL Classroom through Internet Activities." The Internet TESL Journal, Vol. VI, No. 4, April 2000. www. iteslj.org 
Priyatno, Duwi, 2012. Belajar Cepat Olah Data Statistik dengan SPSS. Yogyakarta: Penerbit Andi.

Papaioannou, Photos and Kyriacos Charalambous. 2011. "Principals' Attitudes towards ICT and Their Perceptions about the Factors That Facilitate or Inhibit ICT Integration in Primary Schools of Cyprus.” Journal of Information Technology Education. Volume 10, 2011. PP. 349- 368.

Rimando, Grace. 2010. Global Language of English - The Importance of Learning English. EzineArticle. http:// ExineArticle.Com Submitted On September 18, 2010.

Suraj. 2012. Role of English Language in Globalization. Hubpages. http:// suraj06.hubpages.com/hub/Role-ofEnglish-Language-in-Globalization.

Sander, Tina. 2004. Santa Cruz Adult School, http://www. mnabe-distance learning.org

Yaman, Metin and Yaman, Çetin. 2014. "The Use of Social Network Sites by Prospective Physical Education And Sports Teachers (Gazi University Sample)." The Turkish Online Journal of Educational TechnologyJanuary 2014, volume 13 issue 1. Pp. 223-231. 